\title{
Use of Chemical Flocculation and Nested PCR for Heterodera glycines Detection in DNA Extracts from Field Soils with Low Population Densities
}

Richard Baidoo, Guiping Yan, and Berlin Nelson, North Dakota State University, Department of Plant Pathology, Fargo, 58108; Andrea M. Skantar, USDA-ARS, Nematology Laboratory, Beltsville, MD 20705; and Senyu Chen, University of Minnesota, Department of Plant Pathology, St. Paul, 55108

\begin{abstract}
The soybean cyst nematode (SCN) Heterodera glycines is a major pathogen of soybean worldwide. Distinction between SCN and other members of the $H$. schachtii sensu stricto group based on morphology is a tedious task. A molecular assay was developed to detect SCN in field soils with low population densities and to differentiate SCN from other species. Various numbers of SCN eggs or juveniles were inoculated into $10 \mathrm{~g}$ of sterilized soil from which soil DNA was extracted using the PowerSoil DNA Isolation Kit. A specific amplicon was amplified using published SCNspecific primers SCNF1/SCNR1. This primer set was evaluated for the first

time to detect SCN directly in soil DNA extracts. The specificity of the primers was confirmed by testing 36 isolates of other nematode species. The PCR assay detected one SCN egg or juvenile added to $10 \mathrm{~g}$ of soil. The assay was validated using 35 field soil samples. Grinding the field soil coupled with PCR inhibitor removal by $\mathrm{AlNH}_{4}\left(\mathrm{SO}_{4}\right)_{2} 0.12 \mathrm{H}_{2} \mathrm{O}$ treatment of soil DNA extracts followed by nested PCR enabled SCN detection as low as 12 SCN eggs/200 g soil. The PCR assay not only provides a sensitive method for SCN detection at low densities but also provides a discrimination method for $\mathrm{SCN}$ from other closely related nematodes.
\end{abstract}

The soybean cyst nematode (SCN) Heterodera glycines is considered the most damaging pathogen of soybean in the U.S.A. Annual yield losses in soybean due to SCN have been estimated at more than $\$ 1$ billion in the U.S.A. (Wrather et al. 2001). The nematode was first observed in 1915 in Japan (Hori 1916) but was described as a new species, $H$. glycines, in 1952 (Ichinohe 1952). It is now reported in many countries. In 1954, the nematode was first reported in the U.S.A. in North Carolina and believed to have been introduced from Asia (Riggs 2004; Winstead et al. 1955). Since then, the nematode has been reported throughout soybean producing areas in many states (Tylka and Marett 2014). SCN was first reported in North Dakota in 2003 (Bradley et al. 2004).

$\mathrm{SCN}$ is a member of the $H$. schachtii group, which includes species that are closely related and can only be differentiated based on subtle morphological and morphometric differences (Baldwin and MundoOcampo 1991; Graney and Miller 1982; Sikora and Maas 1985). Distinction between SCN and other H. schachtii members based on morphology and morphometrics is not only tedious, but also time consuming and requires a high technical expertise. Recent advances in molecular techniques have presented a viable alternative to the traditional diagnostic methods. A major development in molecular diagnostic methods is PCR. PCR followed by restriction fragment length polymorphism (PCR-RFLP) of the internal transcribed spacer (ITS) regions of the ribosomal DNA (rDNA) has been frequently used to identify cyst-forming nematodes (Ou et al. 2008a; Subbotin et al. 1999, 2000; Yan and Smiley 2010; Zheng et al. 2000). Members of the $H$. avenae group were discriminated based on rDNA-RFLP (Subbotin et al. 1999, 2003). H. glycines was distinguished from other members of the $H$. schachtii sensu stricto group (H. ciceri, H. medicaginis, $H$. schachtii, and $H$. trifolii) by restriction enzyme AvaI (Subbotin et al. 2000; Zheng et al. 2000). Similarly, PCR assays with speciesspecific primers or primer combinations in multiplex PCR have been developed for the identification of $H$. glycines (Li et al. 2014; Lopez-Nicora et al. 2012; Ou et al. 2008b; Subbotin et al. 2001; Ye 2012). These methods allowed the detection of one or several species in a mixture by a single PCR test, minimizing diagnostic time and

Corresponding author: Guiping Yan; E-mail: guiping.yan@ndsu.edu

Accepted for publication 24 February 2017.

() 2017 The American Phytopathological Society costs. The use of the species-specific primers coupled with quantitative real time PCR also allowed for identification and quantification of nematode species (Goto et al. 2009; Li et al. 2014; Yan et al. 2013a; Ye 2012).

Conventionally, most published molecular detection methods for $\mathrm{SCN}$ require nematode extraction from the soil prior to DNA extraction and amplification (Ou et al. 2008a, b; Sato et al. 2007; Subbotin et al 2001; Ye 2012), which increases detection time, cost, and labor. New technologies have paved the way for molecular detection of SCN or other plant-parasitic nematodes directly in soil DNA extracts (Goto et al. 2009; Li et al. 2014; Showmaker et al. 2011; Yan et al. 2008, 2012, 2013a,b). Using soil compaction and real-time PCR, Goto et al. (2009) could directly detect as low as 10 SCN eggs artificially inoculated into $20 \mathrm{~g}$ of soil. Recently, Li et al. (2014) reported an SCN detection assay in which $1 \mathrm{SCN}$ juvenile inoculated into $0.3 \mathrm{~g}$ of field soil (667 SCN juveniles / $200 \mathrm{~g}$ of soil) could be detected. However, a major challenge with PCR amplification directly from soil DNA extracts is that many soils contain organic compounds such as humic acids that hinder PCR amplification by inhibiting Taq DNA polymerase function (Braid et al. 2003; Kageyama et al. 2003; Porteous and Armstrong 1991; Tsai and Olson 1992), and their removal is both labor and time intensive. These assays, though providing a framework for molecular diagnostics of SCN from metagenomic DNA isolated directly from field soil, did not test other members of the H. schachtii group for distinguishing SCN from these closely related species. Further, the assays did not address the problems of PCR inhibitors associated with soil DNA extracts in different soil textural classes.

Chemical flocculation or the use of multivalent cations to cause suspended particles in liquids to form flocs or aggregates to aid sedimentation and filterability has been a standard practice during purification of drinking water (Edzwald 2011; Kawamura 2000). It was therefore conjectured that, during sample lysis and homogenization during soil DNA extraction, chemical flocculation could be used to remove organic PCR inhibitors (Braid et al. 2003). The use of two sets of primers in two successive runs of PCR (nested PCR) has been utilized to increase both specificity and sensitivity of DNA amplification: less than one cell of Erwinia amylovora from pure culture was detected with nested PCR, representing an increase in sensitivity of 1,000-fold compared with a single-round PCR (McManus and Jones 1995). Further, using a combination of nested PCR and a PCR inhibitors removal procedure, Llop et al. (2000) reported an increased specificity and sensitivity of E. amylovora detection in infected material with nested PCR (78\%) compared with standard PCR (55\%). The goal of this study was 
therefore to develop a sensitive molecular detection assay for SCN in different soil textural classes. The specific objectives were to utilize molecular procedures to detect SCN directly in field soils with low population densities, and to differentiate SCN from sugar beet cyst nematode (H. schachtii) and other closely related cyst nematodes.

\section{Materials and Methods}

Nematode sampling and extraction from soil. A total of 35 field soil samples harboring a range of SCN population densities from five major soybean producing counties (Cass, Richland, Barnes, Dickey, and Ramsey) in ND with a history of soybean production were collected in 2015 for the experiment (Table 1) (Bradley et al. 2004; Yan and Plaisance 2016). Each soil sample was thoroughly mixed and a subsample of $400 \mathrm{~g}$ was collected and divided in half for molecular detection of SCN and traditional egg extraction and quantification. SCN cysts and eggs were extracted from soil samples using the sieving/ decanting and centrifugal sugar floatation method (Jenkins 1964). Briefly, $200 \mathrm{~g}\left(\sim 100 \mathrm{~cm}^{3}\right)$ of field soil was stirred in a beaker with tap water $(200 \mathrm{ml})$ and after $30 \mathrm{~s}$ was poured through a stack of sieves ( $1 \mathrm{~mm}, 250 \mu \mathrm{m}$, and $20 \mu \mathrm{m}$ apertures). Stirring not only helps break up soil particles and detach nematodes from soil particles, but also creates an undercurrent to keep the cysts afloat in the suspension while soil particles settle. The large organic and inorganic particles were collected on the $1 \mathrm{~mm}$ sieve, whereas the cysts and the vermiform nematodes were collected on the $250-\mu \mathrm{m}$-aperture and $20-\mu \mathrm{m}$-aperture sieves, respectively. The vermiform nematodes were resuspended in $30 \mathrm{ml}$ of tap water and centrifuged at 3,500 RPM for $10 \mathrm{~min}$ and the supernatant was discarded. The pellet was resuspended in $30 \mathrm{ml}$ of $1.3 \mathrm{M}$ sugar solution and centrifuged at 3,500 RPM for $30 \mathrm{~s}$. The supernatant containing the nematodes was collected in $15 \mathrm{ml}$ of tap water for quantification using a microscope and the density was expressed as number of $\mathrm{J} 2$ per $200 \mathrm{~g}$ of soil. Cysts collected onto the $250 \mu \mathrm{m}$ sieve were transferred into a customized cylindrical PVC pipe $(7.6 \mathrm{~cm} \times 4 \mathrm{~cm})$ opened from the top but lined with a piece of $250-\mu \mathrm{m}$-aperture sieve at the bottom in which the cysts were crushed with a MasterForce Drill Press with Laser Crosshair (Menards, Fargo, ND) revolving at 650 RPM for $2 \mathrm{~min}$. The eggs were collected onto a $20 \mu \mathrm{m}$ mesh sieve and finally washed into a $45 \mathrm{ml}$ vial with $30 \mathrm{ml}$ of water. The number of eggs or juveniles per $200 \mathrm{~g}$ of soil was quantified using an Axio Scope.A1 microscope at 12V, 100W (Carl Zeiss Inc., U.S.A.).

DNA extraction from nematodes and soil. A single cyst was transferred into $50 \mu \mathrm{l}$ of distilled water on a concave glass slide and crushed with a dental pick. Each individual egg was similarly crushed with the dental pick. The $50 \mu l$ suspension containing nematode pieces was pipetted into a $0.5 \mathrm{ml}$ sterile Eppendorf tube containing $50 \mu \mathrm{l}$ of extraction buffer $(10 \mu \mathrm{l}$ of $10 \times$ PCR buffer, $10 \mu \mathrm{l}$ of $600 \mu \mathrm{g} / \mathrm{ml}$ Proteinase $\mathrm{K}$, and $30 \mu \mathrm{l}$ of sterile water) and the tubes were incubated at $-20^{\circ} \mathrm{C}$ for $20 \mathrm{~min}$ followed by $1 \mathrm{~h}$ incubation at $65^{\circ} \mathrm{C}$ and then $10 \mathrm{~min}$ incubation at $95^{\circ} \mathrm{C}$ (Subbotin et al. 2001). The DNA suspension was stored at $-20^{\circ} \mathrm{C}$ and used as DNA template. The same procedure was followed to extract DNA from vermiform nematode species except that the final DNA suspension was $40 \mu$ l.

Total genomic DNA was extracted from soil samples using the MoBio PowerSoil DNA Isolation Kit (MOBIO Laboratories Inc, Carlsbad, CA) according to the manufacturer's protocol with modifications. Briefly, $0.25 \mathrm{~g}$ of soil sample was added to the PowerBead tubes containing homogenizing and lysis buffer and was gently vortexed to mix. Sixty microliters of solution C1 (lysis butter) was added to the tubes and vortexed briefly. The PowerBead tubes were secured horizontally in the MOBIO Vortex Adapter tube holder and vortexed

Table 1. Origin, field conditions, and the edaphic characteristics of soil from Heterodera glycines fields sampled in North Dakota for the study

\begin{tabular}{|c|c|c|c|c|c|c|c|c|c|c|}
\hline Field ID & Soil textural class & $\%$ Sand & $\%$ Silt & $\%$ Clay & pH & Current crop & Previous year's & Growth stage $^{a}$ & City & County \\
\hline HG-2 & Loam & 54.5 & 35.5 & 10 & 8.0 & Soybean & - & Emergence & Amenia & Cass \\
\hline HG-6 & Loam & 39 & 36 & 25 & 6.1 & - & Soybean & - & Arthur & Cass \\
\hline HG-101 & Loam & 52 & 28 & 20 & 7.9 & Soybean & Corn & Maturity & Colfax & Richland \\
\hline HG-24 & Loam & 40.5 & 39.5 & 20 & 7.6 & Wheat & Soybean & Emergence & Ayr & Cass \\
\hline HG-35 & Silt loam & 39 & 41 & 20 & 7.9 & Soybean & Corn & $\mathrm{VC}$ & Buffalo & Cass \\
\hline HG-48 & Silt loam & 40.5 & 44.5 & 15 & 7.8 & Corn & Soybean & Emergence & Colfax & Richland \\
\hline HG-70 & Silt loam & 40 & 40 & 20 & 7.4 & Soybean & - & $\mathrm{V} 2$ & Crary & Ramsey \\
\hline HG-18 & Silty clay & 8 & 37 & 55 & 7.7 & Soybean & Soybean & Emergence & Gardener & Cass \\
\hline HG-32 & Clay loam & 54.5 & 15.5 & 30 & 7.9 & Soybean & Corn & Emergence & Buffalo & Cass \\
\hline HG-33 & Clay loam & 39 & 31 & 30 & 7.6 & Wheat & Soybean & Tillering & Oriska & Barnes \\
\hline HG-56 & Clay loam & 35.5 & 34.5 & 30 & 7.8 & Soybean & Corn & Pre-emergence & Hankinson & Richland \\
\hline HG-62 & Clay loam & 55.5 & 4.5 & 40 & 7.9 & Corn & Soybean & $\mathrm{V} 2$ & Lindgerwood & Richland \\
\hline HG-5 & Sandy loam & 60 & 35 & 5 & 6.5 & Soybean & - & $\mathrm{VC}$ & Erie & Cass \\
\hline HG-12 & Sandy loam & 70.5 & 9.5 & 20 & 8.0 & - & Corn & - & Hunter & Cass \\
\hline HG-50 & Sandy loam & 72 & 18 & 10 & 6.3 & Soybean & Corn & Pre-emergence & Walcott & Richland \\
\hline HG-51 & Sandy loam & 62 & 28 & 10 & 7.5 & Soybean & Corn & Pre-emergence & Hankinson & Richland \\
\hline HG-52 & Sandy loam & 65.5 & 29.5 & 5 & 7.7 & Corn & Soybean & Emergence & Hankinson & Richland \\
\hline HG-38 & Silty clay loam & 31.5 & 38.5 & 30 & 7.8 & Soybean & Corn & Emergence & Buffalo & Cass \\
\hline HG-42 & Silty clay loam & 23.5 & 41.5 & 35 & 7.7 & Soybean & Corn & Pre-emergence & Colfax & Richland \\
\hline HG-34 & Silty clay loam & 35.5 & 24.5 & 40 & 7.8 & Corn & Soybean & $\mathrm{V} 2$ & Tower City & Barnes \\
\hline HG-64 & Silty clay loam & 32 & 33 & 35 & 6.8 & Soybean & Corn & V1 & Oakes & Dickey \\
\hline HG-31 & Sandy clay loam & 60.5 & 9.5 & 30 & 7.6 & Wheat & Soybean & Tillering & Buffalo & Cass \\
\hline HG-82 & Sandy clay loam & 61.5 & 8.5 & 30 & 7.9 & Corn & - & - & Windermere & Richland \\
\hline HG-102 & Sandy clay loam & 63 & 12 & 25 & 7.8 & Soybean & Corn & Maturity & Hankinson & Richland \\
\hline HG-71 & - & - & - & - & - & Soybean & Soybean & V1 & Devil's Lake & Ramsey \\
\hline HG-4 & - & - & - & - & - & Soybean & - & Pre-emergence & Amenia & Cass \\
\hline HG-17 & - & - & - & - & - & Soybean & wheat & - & Casselton & Cass \\
\hline HG-22 & - & - & - & - & - & Corn & Soybean & V1 & Ayr & Cass \\
\hline HG-60 & - & - & - & - & - & Soybean & Corn & $\mathrm{VC}$ & Lindgerwood & Richland \\
\hline HG-29 & - & - & - & - & - & Corn & Corn & V1 & Page & Cass \\
\hline Y2-HG-131 & - & - & - & - & - & - & - & - & - & Richland \\
\hline Y2-HG-139 & - & - & - & - & - & - & - & - & - & Richland \\
\hline Y2-HG-7 & - & - & - & - & - & - & - & - & - & Richland \\
\hline $\mathrm{W}-1$ & & & & & & Soybeans & - & $\mathrm{V} 2$ & - & Burke \\
\hline W-9 & & & & & & Wheat & - & V1 & - & Divide \\
\hline
\end{tabular}

a Plant growth stage at sampling: VC, unrolled unifoliolate leaf; V1, first trifoliolate leaf; V2, second trifoliolate leaf. 
at maximum speed for 10 min followed by centrifugation at $10,000 \times \mathrm{g}$ for $30 \mathrm{~s}$ at room temperature. All the centrifugations were carried out at $10,000 \times \mathrm{g}$ at room temperature. The supernatant $(500 \mu \mathrm{l})$ was transferred into a clean $2 \mathrm{ml}$ collection tube. Solution C2 containing inhibitor removal solution was added and vortexed for $5 \mathrm{~s}$ followed by incubation at $4^{\circ} \mathrm{C}$ for $5 \mathrm{~min}$. The tubes were centrifuged for $1 \mathrm{~min}$ and $600 \mu \mathrm{l}$ of the supernatant was transferred into a clean $2 \mathrm{ml}$ collection tube. Two hundred microliters of solution $\mathrm{C} 3$ was added to the tubes and vortexed briefly before incubation at $4^{\circ} \mathrm{C}$ for $5 \mathrm{~min}$. The tubes were centrifuged for $1 \mathrm{~min}$ and $650 \mu \mathrm{l}$ of the supernatant was transferred into a clean $2 \mathrm{ml} \mathrm{col}-$ lection tube. Solution $\mathrm{C} 4$, a high concentration salt solution $(1.2 \mathrm{ml})$, was added to the supernatant and vortexed for $5 \mathrm{~s}$. Approximately $675 \mu \mathrm{l}$ of the resulting solution was loaded onto a spin filter and centrifuged for $1 \mathrm{~min}$. This step was repeated two more times for a total of three loads, discarding the flowthrough each time. The DNA bound to the silica membrane was washed with $500 \mu \mathrm{l}$ of solution C5 and centrifuged for $30 \mathrm{~s}$ followed by another centrifugation for $1 \mathrm{~min}$ to remove residual solution C5. The supernatant was finally eluted in $80 \mu$ l of nuclease free water instead of solution $\mathrm{C} 6$ and stored at $-20^{\circ} \mathrm{C}$ until used.

Primer selection and evaluation for SCN specificity. Five primer pairs including GlyF1/rDNA2 (Subbotin et al. 2001), SCNF1/ SCNR1 (Ou et al. 2008b), SCN44F/SCN124R (Goto et al. 2009), $\mathrm{HgSNOF/HgSNOR} \mathrm{(Lopez-Nicora} \mathrm{et} \mathrm{al.} \mathrm{2012),} \mathrm{and} \mathrm{SCNrtF/SCNrtR}$ (Ye 2012) previously reported specific to SCN were screened for specificity to SCN using SCN and other plant-parasitic nematodes. These included eight isolates of Heterodera spp., three isolates of Cactodera spp., six isolates of Globodera spp., two isolates of Meloidogyne spp., and 17 isolates of other plant-parasitic nematodes commonly found in soybean fields in ND such as Helicotylenchus sp., Hoplolaimus sp., Pratylenchus sp., and Paratrichodorus sp. (Table 2). These nematodes were in the collections of the authors. After a series of PCR amplifications, the SCNF1/SCNR1 primer set was eventually selected for the detection experiment. The species-specific primer set SCNF1/ SCNR1 was designed by Ou et al. (2008b) to target a 477 bp randomly amplified polymorphic DNA-sequence characterized amplified region (RAPD-SCAR) marker, OPA06477 (GenBank accession no. DQ354374). The specificity of the primer set to SCN was again verified in silico using the BLAST search at NCBI for homologies and possible nontarget amplification.

PCR amplifications. Species detection and identification were primarily performed using the forward primer SCNF1: 5'-GGA CCCTGACCAAAAAGTTTCCGC- $3^{\prime}$ and reverse primer SCNR1: 5'-GGACCCTGACGAGTTATGGGCCCG-3' with slight modifications in amplification conditions. PCR amplifications were carried out in $20 \mu \mathrm{l}$ reaction volumes containing $4 \mu \mathrm{l}$ of $5 \times$ Green GoTaq Flexi buffer, $0.3 \mu \mathrm{l}$ of each $10 \mathrm{mM}$ forward and reverse primers, $1.2 \mu \mathrm{l}$ of $25 \mathrm{mM} \mathrm{MgCl}_{2}, 0.4 \mu \mathrm{l}$ of $10 \mathrm{mM}$ dNTPs, $2 \mu \mathrm{l}$ of DNA template, 0.5 units of GoTaq Flexi DNA Polymerase (Promega), and $11.4 \mu \mathrm{l}$ of PCR grade water supplemented with bovine serum albumin (BSA) at final concentration of $1 \mu \mathrm{g} / \mu \mathrm{l}$ (Yan et al. 2008). The amplification conditions consisted of an initial denaturation at $94^{\circ} \mathrm{C}$ for 4 min followed by 40 cycles of $94^{\circ} \mathrm{C}$ for $30 \mathrm{~s}, 66^{\circ} \mathrm{C}$ for

Table 2. Plant-parasitic nematodes used to evaluate SCNF1/SCNR1 primer specificity

\begin{tabular}{|c|c|c|c|c|c|}
\hline Code & Species & Host & Origin & Source & Reference \\
\hline $\mathrm{Ht}^{\mathrm{a}}$ & Heterodera trifolii & Clover & U.S.A. & S. Chen & - \\
\hline $\mathrm{H}+53^{\mathrm{a}}$ & H. trifolii & Sweet peas & Greece & A. Skantar & - \\
\hline $\mathrm{Ha}$ & H. avenae & Wheat & U.S.A. & R. Smiley & Yan et al. $(2013 a, b)$ \\
\hline $\mathrm{Hs}$ & H. schachtii & Sugar beet & U.S.A. & B. Nelson & Nelson et al. (2012) \\
\hline $\mathrm{Hf}$ & H. filipjevi & Wheat & U.S.A. & R. Smiley & Yan et al. (2013a) \\
\hline $\mathrm{Hz}^{\mathrm{a}}$ & H. zeae & Potato & Egypt & A. Skantar & - \\
\hline $\mathrm{Hso}^{\mathrm{a}}$ & H. schachtii & Sugar beet & U.S.A. & A. Skantar & - \\
\hline $\mathrm{Hc}$ & H. ciceri & Chickpea & Syria & F. Toumi & Yan et al. (2013a) \\
\hline $\mathrm{Cw}^{\mathrm{a}}$ & Cactodera weissi & Potato & U.S.A. & A. Skantar & - \\
\hline $\mathrm{Cm} 69^{\mathrm{a}}$ & C. milleri & Quinoa & U.S.A. & A. Skantar & - \\
\hline $50 \mathrm{C} 1^{\mathrm{a}}$ & C. milleri & Potato & U.S.A. & A. Skantar & - \\
\hline $\mathrm{Ge}$ & Globodera ellingtonae & Potato & U.S.A. & A. Skantar & Handoo et al. (2012) \\
\hline $\mathrm{Gp}$ & G. pallida & Potato & U.S.A. & A. Skantar & Skantar et al. (2007) \\
\hline Gr56 & G. rostochiensis & Potato & Canada & A. Skantar & Handoo et al. (2012) \\
\hline Gr38 & G. rostochiensis & Potato & U.S.A. & A. Skantar & Skantar et al. (2007) \\
\hline Gt & G. tabacum tabacum & Tobacco & U.S.A. & A. Skantar & Skantar et al. (2007) \\
\hline Gtc & G. tabacum tabacum & Tobacco & U.S.A. & A. Skantar & Skantar et al. (2007) \\
\hline Mn & Meloidogyne naasi & Bentgrass & U.S.A. & A. Skantar & McClure et al. (2012) \\
\hline $\mathrm{Mc}^{\mathrm{a}}$ & M. chitwoodi & Potato & U.S.A. & A. Skantar & - \\
\hline $\mathrm{Pp} 31^{\mathrm{a}}$ & Pratylenchus penetrans & Corn & U.S.A. & A. Skantar & - \\
\hline PnY34 & P. neglectus & Wheat & U.S.A. & G. Yan & Yan et al. (2016b) \\
\hline Pzs & P. zeae & Spider lily & Singapore & A. Skantar & Yan et al. (2013b) \\
\hline Pz $8^{\text {b }}$ & P. zeae & - & - & A. Skantar & - \\
\hline Ps & P. scribneri & Potato & U.S.A. & G. Yan & Yan et al. (2016a) \\
\hline Ps-c & P. scribneri & Corn & U.S.A. & A. Skantar & Yan et al. (2016a) \\
\hline $\mathrm{Pt}$ & P. thornei & Wheat & U.S.A. & R. Smiley & Yan et al. $(2013 a, b)$ \\
\hline $\mathrm{PtP}^{\mathrm{a}}$ & P. thornei & Potato & U.S.A. & A. Skantar & - \\
\hline $\mathrm{Ph} 82^{\mathrm{a}}$ & P. hexincisus & Corn & U.S.A. & A. Skantar & - \\
\hline Stb1 & Paratrichodorus allius & Potato & U.S.A. & G. Yan & Yan et al. (2016c) \\
\hline $\mathrm{MB}-3^{\mathrm{c}}$ & P. allius & Soybean & U.S.A. & G. Yan & Yan and Plaisance (2016) \\
\hline $\mathrm{Hg} 13^{\mathrm{c}}$ & Hoplolaimus sp. & Soybean & U.S.A. & G. Yan & Yan and Plaisance (2016) \\
\hline $\operatorname{Mn} 36^{c}$ & Mesocriconema sp. & Soybean & U.S.A. & G. Yan & Yan and Plaisance (2016) \\
\hline \multirow[t]{4}{*}{$\mathrm{Hg} 22^{\mathrm{c}}$} & Helicotylenchus sp. & Soybean & U.S.A. & G. Yan & Yan and Plaisance (2016) \\
\hline & Paratylenchus sp. & Soybean & U.S.A. & G. Yan & Yan and Plaisance (2016) \\
\hline & Pratylenchus sp. & Soybean & U.S.A. & G. Yan & Yan and Plaisance (2016) \\
\hline & Xiphinema sp. & Soybean & U.S.A. & G. Yan & Yan and Plaisance (2016) \\
\hline $\mathrm{Hg}^{\mathrm{a}}$ & H. glycines & Soybean & U.S.A. & G. Yan & Yan and Plaisance (2016) \\
\hline
\end{tabular}

\footnotetext{
${ }^{\mathrm{a}}$ Reference is not available.

${ }^{\mathrm{b}}$ Host, origin, and reference information is not available.

c Samples were obtained from soybean fields in North Dakota.
} 
$30 \mathrm{~s}$, and $72^{\circ} \mathrm{C}$ for $1 \mathrm{~min}$, and with a final extension cycle of $72^{\circ} \mathrm{C}$ for $10 \mathrm{~min}$. After DNA amplification, $8 \mu \mathrm{l}$ of PCR product was run and separated on $2 \%$ agarose by gel electrophoresis $(95 \mathrm{~V}$ for $30 \mathrm{~min}$ ) and stained with ethidium bromide. The gel was visualized and photographed under UV light using AlphaImager Gel Documentation System (Proteinsimple Inc., Santa Clara, CA). The presence and quality of nematode DNA from soil samples was verified by a pair of universal primers D2A/D3B (Subbotin et al. 2008). A nested-PCR was performed using the forward primer SCNrtF (5'-AAATTCCAGGCCGCTATCTC-3' and the reverse primer SCNrtR: 5'-CGTGGACTGAACTGGACA AAG-3' (Ye 2012). This primer set amplifies a 148 bp fragment within the OPA06477 RAPD-SCAR marker region. The amplification conditions for SCNrtF/SCNrtR were the same as for SCNF1/SCNR1 except that $0.5 \mu \mathrm{l}$ of template DNA was used and the number of PCR cycles was reduced to 30

PCR detection sensitivity and its improvement. A fine, smectitic, frigid Typic Epiaquerts soil (field HG-29) that did not have any detectable SCN and was cultivated to corn in the previous year was collected from Page, Cass County, ND. The soil, while moist, was autoclaved $\left(121^{\circ} \mathrm{C}, 115 \mathrm{kPa}\right)$ for $30 \mathrm{~min}$ and used to determine the detection sensitivity. An SCN cyst was crushed to release eggs into distilled water on a concave glass slide and various numbers $(0,1,2,3,4,5,6,7$, and 8$)$ of the eggs were added separately to $0.25 \mathrm{~g}$ of the freshly autoclaved soil with a glass pipette under a microscope. Detection sensitivity was also tested by adding varying numbers $(0,1,2,3,4,5,6,7$, and 8$)$ of SCN eggs or juveniles to $10 \mathrm{~g}$ of the autoclaved soil. Each infested soil sample was then mixed thoroughly and ground before DNA was extracted from $0.25 \mathrm{~g}$ subsample. DNA extraction and PCR amplification were carried out in triplicate with the SCNF1/SCNR1 primer set for each level of infestation. Pure DNA from SCN was used as a positive control and water as a negative control. The sensitivity of PCR detection was determined by the minimum number of nematodes producing visible amplicons on a $2.0 \%$ agarose gel.

To further evaluate the effects of grinding SCN-infested soil on detection sensitivity and efficiency, grinding experiments were conducted. Two separate trials involving two treatments were conducted. In the first trial, $20 \mathrm{~g}$ of autoclaved HG-29 field soil was infested with a single cyst and either ground or unground in triplicate before DNA extraction. Similarly, in the second trial, $20 \mathrm{~g}$ of the autoclaved field soil was infested with $10 \mathrm{SCN}$ eggs and either ground or unground in triplicate. Grinding of infested soil was manually carried out in a $70 \times 90 \mathrm{~mm}$ porcelain mortar with pestle (VWR, Radnor, PA) for 4 min to obtain a smooth, homogenous texture. DNA was extracted from $0.25 \mathrm{~g}$ of either ground or unground soil and amplified with the SCN species-specific primer set SCNF1/SCNR1. Detection efficiency was assessed by the proportion of the total number of nematodes inoculated detectable by the PCR assay.

Testing for the presence of PCR inhibitors in soil DNA extracts. To test for the presence of PCR inhibitors in the soil DNA extracts, a dilution experiment was performed. DNA from a single SCN cyst was serially diluted with soil DNA extracts from the field sample HG-51 (Tables 1 and 2) to obtain 1:1, 1:2, 1:4, 1:6, 1:8, and 1:10 serial dilutions of SCN DNA suspension. Similarly, the SCN DNA was also diluted with PCR grade water to obtain the same dilution series and used as a control. The SCN DNA at different levels of dilution was amplified using SCN-specific primer set SCNF1/SCNR1. Inhibition of PCR was defined by one of the following characteristics: a lack of product and primer dimers, or the appearance of primer dimers without a clear or visible PCR product according to Braid et al. (2003).

Removal of PCR inhibitors. To remove PCR inhibitors from soil DNA extracts, the effects of aluminum ammonium sulfate, $\mathrm{AlNH}_{4}\left(\mathrm{SO}_{4}\right)_{2} \cdot 12 \mathrm{H}_{2} \mathrm{O}$ (Mallinckrodt Inc., Hazelwood, $\mathrm{MO}$ ) was tested through its inclusion in the DNA extraction process using the MoBio kit. $\mathrm{AlNH}_{4}\left(\mathrm{SO}_{4}\right)_{2} \cdot 12 \mathrm{H}_{2} \mathrm{O}$ is an inorganic flocculant reported to have reduced soil-based inhibitors during soil DNA extraction (Braid et al. 2003). Two hundred microliters of different concentrations $(50,100$, and $200 \mathrm{mM}$ ) of $\mathrm{AlNH}_{4}\left(\mathrm{SO}_{4}\right)_{2} \cdot 12 \mathrm{H}_{2} \mathrm{O}$ were added to $600 \mu \mathrm{l}$ of the supernatant after the final step in the MoBio patented inhibitor removal procedure (solution $\mathrm{C} 3$ addition, centrifugation, and supernatant removal). The $\mathrm{AlNH}_{4}\left(\mathrm{SO}_{4}\right)_{2} \cdot 12 \mathrm{H}_{2} \mathrm{O}$ plus the supernatant was incubated at room temperature for $10 \mathrm{~min}$ and centrifuged for $1 \mathrm{~min}$ before addition of solution $\mathrm{C} 4$ for binding the DNA to the silica membrane. DNA from HG-51 soil was extracted either with or without $\mathrm{AlNH}_{4}\left(\mathrm{SO}_{4}\right)_{2} \cdot 12 \mathrm{H}_{2} \mathrm{O}$ using the MoBio kit in triplicates. Pure SCN DNA was diluted with different amounts of HG-51 soil DNA extracts that were extracted with or without $\mathrm{AlNH}_{4}\left(\mathrm{SO}_{4}\right)_{2} \cdot 12 \mathrm{H}_{2} \mathrm{O}$ at different concentrations to give a serial dilution of 1:1, 1:2, and 1:4 for each concentration. SCN DNA was diluted with different amounts of water to obtain similar dilutions as controls. DNA at each level of dilution was amplified in the resultant solution using SCNF1/SCNR1. The ability of the flocculant to remove inhibitors was measured by the PCR band intensity variations between soil DNA extracts obtained with or without $\mathrm{AlNH}_{4}\left(\mathrm{SO}_{4}\right)_{2} \cdot 12 \mathrm{H}_{2} \mathrm{O}$ in the serial dilution compared with water control.

SCN detection and discrimination in naturally infested soil. The PCR assay was validated by comparing its detection in fields positive or negative for SCN as determined by the traditional method. The same 35 field samples as previously mentioned were used. These fields had a range of SCN population densities ( 0 to 20,323 eggs and J2 per $200 \mathrm{~g}$ of soil). The soil textural class for each field soil was determined using the hydrometer method (Day 1965) and the $\mathrm{pH}$ was measured using a $\mathrm{pH}$ meter (ASTM 1995). For each field soil sample, $400 \mathrm{~g}$ was collected after thoroughly mixing, and divided in half for molecular detection and traditional egg extraction and quantification (Table 3). SCN egg and cyst extractions were carried out as described above (Jenkins 1964).

For the molecular detection assay, the field soil was air-dried at room temperature in a Petri dish overnight $(9 \mathrm{~h})$ and ground as previously described. The ground soil was fractionated by sieving through a stack of sieves $(710 \mu \mathrm{m}, 425 \mu \mathrm{m})$ and the soil particles/debris/stones on top of each sieve were discarded. The soil particles that passed through the $425-\mu \mathrm{m}$-aperture sieve were collected and used for DNA extraction. This reduced the resultant sample size nearly by half. A subsample of $0.25 \mathrm{~g}$ was collected (by at least 30 small scoops from different parts of the sample using a spatula) and DNA was extracted from the $0.25 \mathrm{~g}$ using the MoBio kit without the addition of the flocculant $\mathrm{AlNH}_{4}\left(\mathrm{SO}_{4}\right)_{2} \cdot 12 \mathrm{H}_{2} \mathrm{O}$. SCN DNA was amplified from the soil DNA extract using the SCN species-specific primer set SCNF1/SCNR1.

To increase SCN detection sensitivity and efficiency in field soils with low SCN population densities ( $<349$ SCN/200 g of soil), a combination of PCR inhibitor removal technique and nested PCR was adopted. The MoBio PowerSoil DNA extraction protocol was modified by adding an extra inhibitor removal step after treatment with solution $\mathrm{C} 3$ described above. Two hundred microliters of $100 \mathrm{mM} \mathrm{AlNH}\left(\mathrm{SO}_{4}\right)_{2} \cdot 12 \mathrm{H}_{2} \mathrm{O}$ was filter-sterilized using a $0.2 \mu \mathrm{m}$ aperture syringe-driven filter unit (Millex-GV, Darmstadt, Germany) and added to the supernatant, which was collected after addition and centrifugation with solution $\mathrm{C} 3$. The supernatant plus $\mathrm{AlNH}_{4}\left(\mathrm{SO}_{4}\right)_{2} \cdot 12 \mathrm{H}_{2} \mathrm{O}$ was kept at $25^{\circ} \mathrm{C}$ for $10 \mathrm{~min}$ and centrifuged for $1 \mathrm{~min}$ at room temperature. The supernatant was collected and solution $\mathrm{C} 4$ was added to continue with the protocol according to the manufacturer's recommendation. The purified DNA was used as template for PCR using the SCNF1/SCNR1 primer set for SCN amplification. To further increase detection sensitivity and efficiency, the SCNF1/SCNR1 products from these samples were used as template for the nested PCR with the SCNrtF/SCNrtR primer set. DNA extractions and PCR amplifications were performed five times for each field sample under the optimum conditions as described above.

\section{Results}

Primer specificity. Most SCN species-specific primers, including HgSNOF/HgSNOR, SCN44F/SCN124R, and SCNrtF/SCNrtR, screened for specificity to SCN, did not clearly separate SCN from the $H$. schachtii and $H$. trifolii populations used in this study. However, the primer sets SCNF1/SCNR1 and GlyF1/rDNA2 amplified the expected amplicons of 477 and $181 \mathrm{bp}$, respectively, for SCN but did not produce any amplicons from any other nematode. Therefore, the primer sets SCNF1/SCNR1 and GlyF1/rDNA2 enabled discrimination of SCN from other plant-parasitic nematodes including three members in the H. schachtii group: H. schachtii, H. trifolii, and H. ciceri (Fig. 1); three other Heterodera cyst nematode species (H. avenae, $H$. filipjevi, and $H$. zeae); and two Cactodera cyst nematode species (C. weissi and $C$. milleri). BLASTn search of the 477 bp RAPD-SCAR marker 
OPA06 $_{477}$ against the nucleotide database in GenBank produced no homology, except to itself (DQ354374).

Detection sensitivity of PCR amplification. The PCR assay could detect one SCN egg or juvenile per $0.25 \mathrm{~g}$ of soil in all three independent DNA extractions and PCR amplifications using both the nematode universal primers D2A/D2B and SCN specific primers SCNF1/ SCNR1. No PCR amplification was observed from uninfested control soil. This detection sensitivity equates to $800 \mathrm{SCN}$ eggs per $200 \mathrm{~g}$ of soil. Much higher detection sensitivity was achieved in another test in which varying numbers of SCN eggs or juveniles $(n=0,1,2,3$, $4,5,6,7$, and 8) were added to $10 \mathrm{~g}$ of autoclaved soil and ground. When DNA was extracted using $0.25 \mathrm{~g}$ of the infested soil and amplified for a 477 bp specific band, the result showed that the PCR assay could detect the minimum of $1 \mathrm{SCN}$ egg or juvenile per $10 \mathrm{~g}$ of soil, representing 20 eggs or juveniles per $200 \mathrm{~g}$ of soil (Fig. 2).
Assessing the effect of grinding field soil on detection efficiency. The results showed that all three samples each with a single cyst added to the $20 \mathrm{~g}$ soil and subsequently ground were detected by the assay, whereas only one of the three samples without grinding was detected by the assay. Similarly, all three replicates of the 10 eggs added to $20 \mathrm{~g}$ of soil and ground before DNA extraction were detected by the assay, while only one of the three replications without grinding were detected by the assay (Fig. 3).

Testing for the presence of PCR inhibitors in field soil extracts. The presence of PCR inhibitors was observed in the soil DNA extract. While amplifications occurred with SCN DNA diluted with soil DNA extracts at 1:1, 1:2, and 1:4, no visible band was observed when SCN DNA was diluted with soil DNA extract at $1: 6,1: 8$, or $1: 10$ ratio. Band intensity decreased with increasing the amount of soil DNA extract diluent. However, dilution of SCN DNA with PCR grade,

Table 3. Comparison of the molecular and traditional Heterodera glycines detection methods using $200 \mathrm{~g}$ of field soil

\begin{tabular}{|c|c|c|c|c|c|c|}
\hline \multicolumn{6}{|c|}{ Traditional detection } & \multirow{2}{*}{$\frac{\text { MA }^{\mathbf{b}}}{\text { Success rate }}$} \\
\hline Field ID & \# Eggs in cysts & \# $\mathrm{J} 2$ in cysts & \# $\mathbf{J} 2$ in soil & Total number of SCN & $\mathbf{P P N}^{\mathbf{a}}$ & \\
\hline$\overline{\mathrm{HG}-101}$ & 17,733 & 2,100 & 490 & 20,323 & 325 & $+5 / 5$ \\
\hline HG-24 & 5,880 & 368 & 35 & 6,283 & 525 & $+5 / 5$ \\
\hline HG-2 & 4,410 & 360 & 360 & 5,130 & 720 & $+5 / 5$ \\
\hline HG-4 & 3,010 & 700 & 52 & 3,762 & 160 & $+5 / 5$ \\
\hline HG-102 & 1,050 & 0 & 0 & 1,050 & 910 & $+5 / 5$ \\
\hline HG-62 & 816 & 70 & 300 & 1,186 & 240 & $+5 / 5$ \\
\hline HG-38 & 510 & 0 & 0 & 510 & 0 & $+5 / 5$ \\
\hline HG-5 & 450 & 0 & 0 & 450 & 1,120 & $+5 / 5$ \\
\hline HG-50 & 350 & 0 & 25 & 375 & 400 & $+5 / 5$ \\
\hline HG-52 & 303 & 53 & 18 & 374 & 60 & $+5 / 5$ \\
\hline HG-17 & 256 & 93 & 0 & 349 & 140 & $+5 / 5$ \\
\hline HG-64 & 210 & 0 & 0 & 210 & 140 & $+3 / 5$ \\
\hline Y2-HG-7 & 0 & 0 & 0 & 200 & 525 & $+4 / 5$ \\
\hline HG-82 & 200 & 0 & 0 & 200 & 1,830 & $+3 / 5$ \\
\hline HG-56 & 150 & 0 & 0 & 150 & 1,080 & $+4 / 5$ \\
\hline HG-71 & 145 & 0 & 0 & 145 & 300 & $+2 / 5$ \\
\hline HG-6 & 140 & 0 & 0 & 140 & 185 & $+2 / 5$ \\
\hline HG-35 & 140 & 0 & 0 & 140 & 360 & $+4 / 5$ \\
\hline Y2-HG-139 & 0 & 0 & 0 & 100 & 44 & $+2 / 5$ \\
\hline HG-70 & 93 & 0 & 0 & 93 & 262 & $+3 / 5$ \\
\hline HG-18 & 90 & 0 & 0 & 90 & 150 & $+3 / 5$ \\
\hline HG-22 & 0 & 0 & 0 & 90 & 2,370 & $+4 / 5$ \\
\hline HG-60 & 0 & 0 & 0 & 90 & 480 & $+5 / 5$ \\
\hline HG-34 & 82 & 0 & 0 & 82 & 90 & $+2 / 5$ \\
\hline HG-51 & 70 & 0 & 0 & 70 & 900 & $+3 / 5$ \\
\hline Y2-HG-131 & 35 & 0 & 28 & 63 & 1,288 & $+2 / 5$ \\
\hline HG-32 & 30 & 0 & 0 & 30 & 245 & $+3 / 5$ \\
\hline HG-12 & 12 & 0 & 0 & 12 & 1,151 & $+2 / 5$ \\
\hline HG-48 & 0 & 0 & 0 & 0 & 360 & $+3 / 5$ \\
\hline HG-42 & 0 & 0 & 0 & 0 & 0 & $+1 / 5$ \\
\hline HG-31 & 0 & 0 & 0 & 0 & 840 & - \\
\hline HG-33 & 0 & 0 & 0 & 0 & 880 & - \\
\hline HG-29 & 0 & 0 & 0 & 0 & 1,000 & - \\
\hline W-1 & 0 & 0 & 0 & 0 & - & $+2 / 5$ \\
\hline W-9 & 0 & 0 & 0 & 0 & - & - \\
\hline
\end{tabular}

a Indicates other plant-parasitic nematodes.

${ }^{\mathrm{b}}$ MA indicates presence (+) or absence (-) of SCN based on the improved molecular assay (soil grinding, sieving, PCR inhibitor removal, and nested PCR).

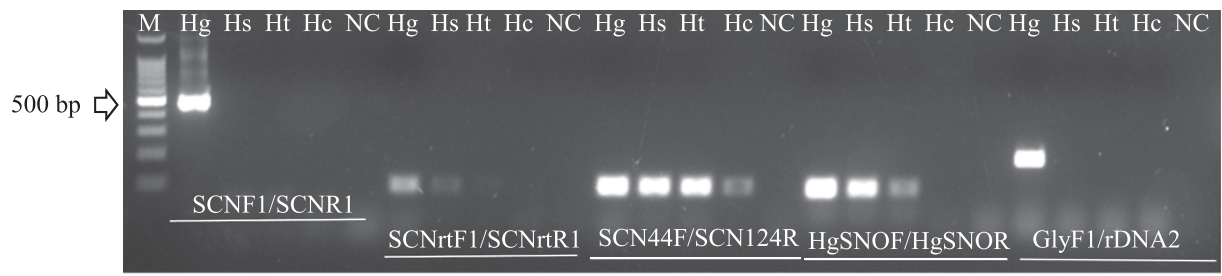

Fig. 1. Evaluation of five Heterodera glycines-specific primer pairs: SCNF1/SCNR1, HgSNOF/HgSNOR, SCN44F/SCN124R, SCNrtF/SCNrtR, and GlyF1/rDNA2. Hg = H. glycines positive control; $\mathrm{Hs}=\mathrm{H}$. schachtii; $\mathrm{Ht}=\mathrm{H}$. trifolii; $\mathrm{Hc}=\mathrm{H}$. ciceri; $\mathrm{NC}=$ water used as template; and $\mathrm{M}, 100-\mathrm{bp} \mathrm{DNA}$ ladder. 
nuclease-free water did not show any inhibition of PCR amplification, strongly suggesting that the HG-51 sandy-loam soil contained PCR inhibitors (Fig. 4).

Removal of PCR inhibitors. When SCN DNA was amplified in the SCN DNA dilutions made with either $\mathrm{AlNH}_{4}\left(\mathrm{SO}_{4}\right)_{2} \cdot 12 \mathrm{H}_{2} \mathrm{O}$ treated extract or water using SCNF1/SCNR1 primer set, the PCR band intensity was found to be stronger in SCN DNA diluted with $\mathrm{AlNH}_{4}\left(\mathrm{SO}_{4}\right)_{2} \cdot 12 \mathrm{H}_{2} \mathrm{O}$-treated soil DNA extracts comparable to dilutions with nuclease-free water. All three different concentrations of $\mathrm{AlNH}_{4}\left(\mathrm{SO}_{4}\right)_{2} .12 \mathrm{H}_{2} \mathrm{O}$ could reduce the level of soil inhibitors compared with the untreated control but there was almost no difference between the three concentrations of $\mathrm{AlNH}_{4}\left(\mathrm{SO}_{4}\right)_{2} \cdot 12 \mathrm{H}_{2} \mathrm{O}$.

SCN detection in field soils with low population densities. The soil textural analysis showed that the soils were generally sandy, with the average percentage of sand, silt, and clay approximately 47,28, and $25 \%$, respectively (Table 1 ). They were classified as loam, silt loam, silty clay, clay loam, sandy loam, silty clay loam, or sandy clay loam with $\mathrm{pH}$ range between 6.1 and 8.0.

When the soil DNA was amplified without the use of $\mathrm{AlNH}_{4}\left(\mathrm{SO}_{4}\right)_{2} \cdot 12 \mathrm{H}_{2} \mathrm{O}$ to reduce soil inhibitors, the results showed that only one of three independent DNA extractions from HG-5 and two of three independent DNA extractions from HG-50 and HG-52 containing 450, 375, and 374 SCN/200 g of soil, respectively, were positive for SCN (Fig. 5). However, SCN was not detected at densities $\leq 210 \mathrm{SCN} / 200 \mathrm{~g}$ of soil including fields HG-64 (210 $\mathrm{SCN} / 200 \mathrm{~g}$ of soil), HG-82 (200 SCN/200 $\mathrm{g}$ of soil), HG-56 (150 SCN/200 $\mathrm{g}$ of soil), HG-6 (140 SCN/200 g of soil), HG-35 (140 SCN/200 $\mathrm{g}$ of soil), HG-34 (82 SCN/200 g of soil) HG-51 (70 $\mathrm{SCN} / 200 \mathrm{~g}$ of soil), HG-32 (30 SCN/200 $\mathrm{g}$ of soil), HG-12 (12 SCN/200 $\mathrm{g}$ of soil), and HG-48 (0 SCN/200 $\mathrm{g}$ of soil), as there was no amplification for any of the three independent DNA extractions.

Improving detection efficiency in field soils with low SCN densities. To improve detection efficiency, a combination of soil grinding and sieving, and inclusion of $\mathrm{AlNH}_{4}\left(\mathrm{SO}_{4}\right)_{2} \cdot 12 \mathrm{H}_{2} \mathrm{O}$ in the extraction process, was followed by a regular PCR with the SCN species-specific primers. The assay was tested on soil samples with high or low SCN densities, or with no detectable SCN infestation. Soil samples with high SCN population densities were HG-101 (20,323 SCN/200 g of soil) and HG-24 (6,283 SCN/200 g of soil). Those with low SCN densities were (HG-12 (12 SCN/200 g of soil), HG-34 (82 SCN/200 g of soil), HG-35 (140 SCN/200 g of soil), HG-6 (140 SCN/200 g of soil), HG-22 (90 SCN/200 g of soil), HG-60 (90 SCN/200 g of soil), HG131 (63 SCN/200 g of soil), HG-139 (100 SCN/200 g of soil), and HG-Y2-7 (200 SCN/200 g of soil). Fields with no detectable number of SCN per $200 \mathrm{~g}$ of soil included HG-29, HG-W-1, HG-W-9, HG-48, and HG-42. When these samples were tested, samples with high SCN densities (HG-101 and HG-24) produced the expected bands for SCN but not all the replicates of samples with low $\mathrm{SCN}$ population produced visible bands except HG-6. Samples HG-60, HG-131, HG-Y2-7, and HG-35 tested positive for SCN (Fig. 6A).

When the PCR product in Figure 6A was used as template in a nested PCR using SCNrtF/SCNrtR primer set, the result (Fig. 6B) confirmed the presence of SCN DNA in HG-101, HG-24, HG-6, HG-60, HG-131, HG-Y2-7, HG-35, and HG-48. It also detected
SCN in HG-52, HG-22, HG-12, HG-W-1, and HG-42. Thus, the assay could detect as low as $12 \mathrm{SCN} / 200 \mathrm{~g}$ of soil (HG-12). Nonetheless, SCN was not detected in HG-29 and HG-W-9 field samples by both traditional and molecular methods. Interestingly, samples HG-48, HG-42, and W-1 tested positive for SCN, even though there was no detectable infestation with the traditional egg extraction method (Table 3 and Fig. 6B). We also observed that SCN detection was efficient and consistent at high population densities ( $>349 \mathrm{SCN} / 200 \mathrm{~g}$ of soil); however, at low population densities ( $<349 \mathrm{SCN} / 200 \mathrm{~g}$ of soil), detection efficiency or consistency was low. The results of five independent DNA extractions and PCR amplifications for the 35 samples tested using this improved assay are summarized in Table 3.

\section{Discussion}

SCN was detected directly in DNA extracts from field soils with low population densities using chemical flocculation and species-specific and nested PCR. In this study, mechanical grinding of field soil was coupled with chemical lysis of microbial cells to enable maximum release of total genomic DNA followed by PCR amplification of a specific target DNA to detect SCN. The assay was highly specific and able to differentiate SCN from the other cyst and non-cyst forming nematodes and other common nematodes in soybean fields tested in this study.

Distinguishing SCN from the other members of the $H$. schachtii sensu stricto group is difficult. The SCN species-specific primers previously reported (Goto et al. 2009; Lopez-Nicora et al. 2012; Ye 2012) produced the expected amplicons for SCN but they also partially amplified DNA from the $H$. schachtii and $H$. trifolii populations used in our study. The inability of SCN species-specific primers to separate SCN from our populations of $H$. schachtii and $H$. trifolii in the $H$. schachtii group reaffirms the intriguing similarity among these nematodes, and the complexity involved in separating closely related species. Conversely, in agreement with our results, the primer sets SCNF1/SCNR1 did not amplify DNA from $H$. avenae, $H$. schachtii, Globodera pallida, and $G$. rostochiensis used as control species (Ou et al. 2008b). Furthermore, our tests demonstrated that the primer set also differentiated SCN from $H$. trifolii and $H$. ciceri in the H. schachtii group, two other Heterodera cyst nematode species (H. filipjevi, H. zeae), two Cactodera cyst species (C. weissi, C. milleri), and all other control species used in this study. Nonetheless,

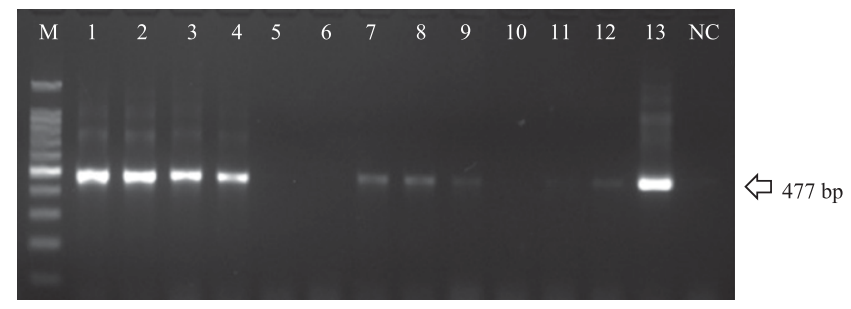

Fig. 3. Effect of grinding the soil on PCR detection efficiency using Heterodera glycines (SCN)-specific primer pair SCNF1/SCNR1. Lanes 1 to 3, a single cyst inoculated into $20 \mathrm{~g}$ of soil and ground; lanes 4 to 6 , a single cyst inoculated into $20 \mathrm{~g}$ of soil but not ground. Lanes 7 to 9, 10 eggs inoculated into $20 \mathrm{~g}$ of soil and ground; lanes 10 to 12 , 10 eggs inoculated into $20 \mathrm{~g}$ of soil but not ground. Lane 13, positive control using DNA from hand-picked SCN; lane NC, negative control with water as template; and lane M, 100-bp DNA ladder.

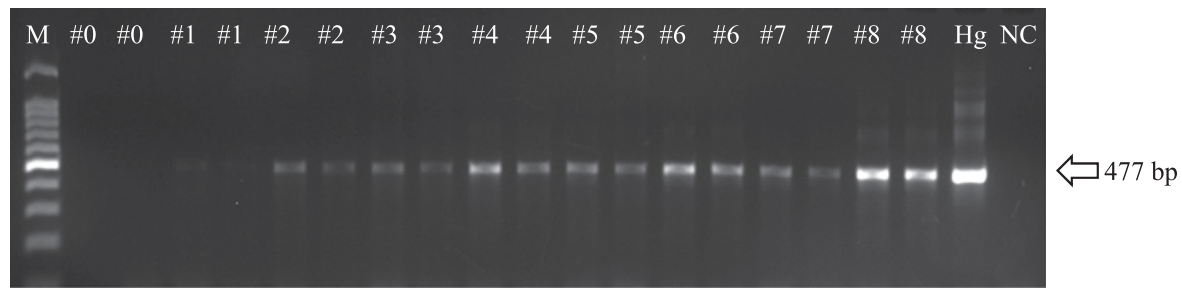

Fig. 2. Level of detection of Heterodera glycines (SCN) eggs by PCR amplification in artificially infested soil using SCN species-specific primer set SCNF1/SCNR1. Numbers of SCN eggs in $10 \mathrm{~g}$ soil: zero (\#0), one egg (\#1), two eggs (\#2), three eggs (\#3), four eggs (\#4), five eggs (\#5), six eggs (\#6), seven eggs (\#7), and eight eggs (\#8). Lane Hg, positive control using DNA from hand-picked SCN. Lane NC, negative control using water as template. M, 100-bp DNA ladder. 
this species-specific primer set was previously tested for specificity only with DNA from nematode materials, but not with soil DNA (Ou et al. 2008 b). This is the first report to detect SCN directly in soil DNA using this primer set. Although not verified, but based on the ability of the SCN RAPD-SCAR marker OPA06 ${ }_{477}$ or its flanking sequences to discriminate SCN from closely related species used in this study, we speculate that the marker is perhaps part of a gene involved in a functional role unique to $\mathrm{SCN}$. The primer set GlyF1/rDNA2 could also separate SCN from H. trifolii, H. cicero, or H. schachtii, we did not use this primer pair due to its potential limitation to be used in the nested PCR and the existence of at least two ITS haplotypes in different proportions in rDNA clusters of the genome of $\mathrm{H}$. glycines (Subbotin et al. 2001; Zheng et al. 2000).

To develop a molecular detection assay to directly detect SCN from soil, the effect of grinding the soil prior to DNA extraction with a commercial DNA extraction kit was demonstrated. This soil grinding step was a modification of a method by Goto et al. (2009), who used soil compaction and real-time $\mathrm{PCR}$ for $\mathrm{SCN}$ detection directly from soil. The detection efficiency for cysts and eggs in the unground soil was lower than the ground soil. This observation agrees with the observation that soil compaction could improve SCN detection (Goto et al. 2009). However, the soil compactor used by Goto et al. (2009) was specialized machinery tailored to this end and not readily available, hence the need for a readily available, low cost method of achieving a comparable results. The effect of grinding on DNA detection was reported for other pathogens. Volossiouk et al. (1995) reported that disruption of Verticillium dahliae by grinding in liquid nitrogen with natural abrasives enabled its direct detection from the soil. Similarly, a rapid freeze-and-thaw method enabled detection of less than 3 Escherichia coli cells/g of infested soil (Tsai and Olson 1992). Therefore, a possible explanation to our observation is that grinding the soil helps break SCN cysts to release embedded eggs and juveniles in the sample to obtain a homogenized $\mathrm{SCN}$ cell/tissue mix with the soil sample, which appears to be a critical factor in detection. Mixing is also important because of the patchy spatial distribution of SCN in soil plus the small amount of soil used for detection. Consistent with this hypothesis, Goto et al. (2009) showed that compacting field soil to $1.4 \mathrm{~g} \mathrm{~cm}^{-3}$ increased the amount of DNA recovered from SCN by 16 times. Nevertheless, grinding field soil can be difficult for heavy and moist soils, but air drying the field soil for at least $8 \mathrm{~h}$ facilitated grinding and made the procedure applicable to the wide range of soil textural classes analyzed in this study. Grinding the soil is therefore essential for efficient SCN detection at densities below $349 \mathrm{SCN} / 100 \mathrm{~cm}^{3}$ of soil.

In detection sensitivity experiments, $1 \mathrm{SCN}$ egg or juvenile was added to $10 \mathrm{~g}$ of autoclaved, SCN-free soil followed by grinding before DNA extraction. This procedure enabled detection of $1 \mathrm{SCN}$ egg or juvenile/10 $\mathrm{g}$ of soil, equivalent to $20 \mathrm{SCN}$ eggs or juveniles/200 $\mathrm{g}$ of soil. This detection sensitivity is higher than those previously reported: 100 SCN/200 $\mathrm{g}$ of soil (Goto et al. 2009); or $1 \mathrm{SCN}$ juvenile/0.3 $\mathrm{g}$ of field soil equivalent to nearly 666 juveniles/200 g of soil (Li et al. 2014). Increased detection sensitivity implies the ability to detect SCN at low population densities, which was the primary goal of this study.

We have also demonstrated that the presence of PCR inhibitors in soil DNA extracts hindered PCR amplification consistent with many reports (Braid et al. 2003; Kageyama et al. 2003; Porteous and Armstrong 1991;

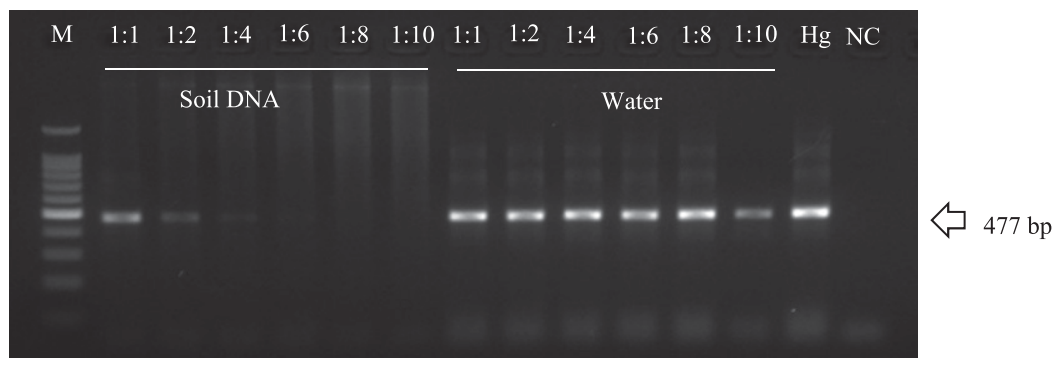

Fig. 4. PCR amplification showing the effect of inhibitors in soil DNA extracts: Heterodera glycines DNA from a single cyst diluted with soil DNA at 1:1, 1:2, 1:4, 1:6, 1:8, and 1:10 compared with the SCN DNA diluted with PCR grade water at 1:1, 1:2, 1:4, 1:6, 1:8, and 1:10, and amplified with primer set SCNF1/SCNR1. Hg, SCN DNA as a positive control; NC, negative control containing water; and M, 100-bp DNA ladder.
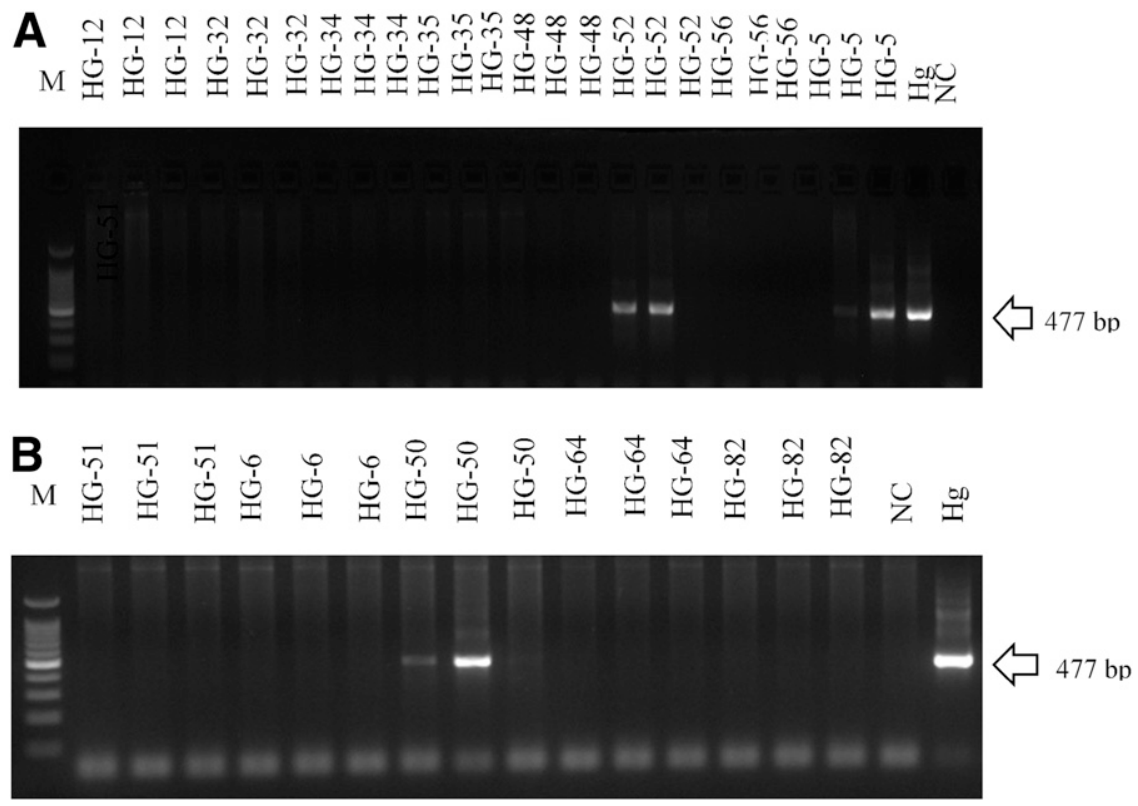

Fig. 5. Detection of $S C N$ in 13 naturally infested soils ( $A$ and B) with low SCN population densities ( $\leq 349 \mathrm{SCN} / 200 \mathrm{~g}$ of soil). Nematode DNA was extracted with MoBio PowerSoil DNA extraction kit without treatment of $\mathrm{AINH}_{4}\left(\mathrm{SO}_{4}\right)_{2} .12 \mathrm{H}_{2} \mathrm{O}$. DNA was amplified with the SCN species-specific primer set SCNF1/SCNR1. Only five samples were positive for SCN. The soil samples were shown in Tables 1 and 3. Hg, SCN positive control; NC, water used as template; and M, 100-bp DNA ladder. 
Tsai and Olson 1992). To remove the PCR inhibitors from the soil, $\mathrm{AlNH}_{4}\left(\mathrm{SO}_{4}\right)_{2} .12 \mathrm{H}_{2} \mathrm{O}$ was used in the extraction process based on the modified protocol by Braid et al. (2003), who used a set of primers to amplify a bacterial $16 \mathrm{~S}$ rDNA gene from environmental soil. They observed that addition of $\mathrm{AlNH}_{4}\left(\mathrm{SO}_{4}\right)_{2} \cdot 12 \mathrm{H}_{2} \mathrm{O}$ to the soil DNA extract during sample lysis and homogenization step using the Ultra-Clean Soil DNA Purification Kit significantly reduced copurification of PCR inhibitors with the bacterial genome. Similarly, we observed that the addition of $\mathrm{AlNH}_{4}\left(\mathrm{SO}_{4}\right)_{2} \cdot 12 \mathrm{H}_{2} \mathrm{O}$ significantly reduced the effects of PCR inhibitors and improved the band intensity at all tested concentrations (50, 100 , and $200 \mathrm{mM}$ ). This method is a reliable and inexpensive alternative to many PCR removal methods including hexadecyltrimethylammoniumbromide (CTAB), polyvinylpolypyrrolidone (PVPP), hydroxyapatite columns, cesium chloride density centrifugations, ion exchange and size exclusion chromatography, and agarose gel electrophoresis followed by excision and DNA extraction from the gel matrix (Cho et al. 1996; Erb and Wagner-Dobler 1993; Frostegard et al. 1999; Holben et al. 1988; Torsvik 1980; Yan et al. 2008, 2012, 2013b).

The PCR assay was validated by testing its SCN detection in 35 fields positive or negative for SCN in ND. We observed that SCN detectability was consistent at high population densities but using just species-specific primers and standard PCR, we observed no or inconsistent amplification for most samples at low densities ( $<349$ eggs/200 g of soil). Increasing the PCR cycle from 40 to 45 did not improve band intensity, showing a response different than DNA samples extracted directly from nematodes. Subsequently, a combination of soil grinding, an inhibitor removal method, and nested PCR was adopted, which improved SCN detection in a wide range of soil textural classes containing low SCN population densities. Using this assay, as low as 12 SCN/200 g of soil could be detected. This detection sensitivity in naturally infested field soils is higher than previously reported. Goto et al. (2009) reported that soil compaction enabled SCN detection (4 cysts/20 g of soil) equivalent to $8,600 \mathrm{SCN} /$ $200 \mathrm{~g}$ of soil. We also detected SCN in HG-42, HG-48, and HG-W-1, which recorded no SCN infestation according to the traditional egg extraction and quantification method. Bellvert et al. (2008) observed that different traditional cyst extraction methods differed in efficiencies ranging from 33 to $84 \%$, implying a high risk of obtaining false negative results with the traditional detection method. Together with our results, it is suggestive that the molecular assay could be more efficient in detecting SCN under low population densities than the traditional method, but more experiments are needed to determine if the molecular method is more sensitive to detect SCN or not. However, both methods detected no SCN in HG-31, HG-33, HG-29, and GH-W-9 samples, which indicates specificity of our assay.

In this study, although we could detect SCN in soil samples with low SCN population densities (below 349 SCN/200 g of soils), detection consistency in naturally infested soils was low compared with $\mathrm{SCN}$ detection in artificially infested soil. These discrepancies could be attributed to a number of factors, including soil type, soil $\mathrm{pH}$, the presence of PCR inhibitors, and low DNA concentration. Bacillus subtilis was shown to adsorb and bind to clay minerals under acidic conditions $(\mathrm{pH}=1)$ (Alvarez et al. 1998; Khanna and Stotzky 1992). Nonetheless, the soils analyzed in this study showed minor variability in $\mathrm{pH}$ levels (6.1 to 8.0), but there was a marked variation in clay content which supposedly conferred some level of inhibition to SCN DNA amplification at low densities.

Removal of PCR inhibitors by treatment of soil DNA extracts with $\mathrm{AlNH}_{4}\left(\mathrm{SO}_{4}\right)_{2} \cdot 12 \mathrm{H}_{2} \mathrm{O}$ improved SCN detectability at low population densities, suggesting that the effect of PCR inhibitors was pronounced in low density soils. In contrast, in soils with SCN numbers above 349 SCN/200 g of soil, inhibition may have occurred but PCR amplification proceeded. Therefore, if the target DNA concentration in the soil DNA extracts is high, PCR amplification will proceed to some level, even in the presence of chemical inhibitors. Conversely, if the target DNA concentration is low, the presence of inhibitors will override PCR amplification. Goto et al. (2009) also suggested that a larger amount of DNA from SCN eggs might bind to soil particles and/or humic substances and become unextractable at low SCN density. Similarly, when DNA is adsorbed to clay particles, more is bound at lower DNA concentrations (Khanna and Stotzky 1992). Tsai and Olson (1992) observed that detection sensitivity of Escherichia coli cells in soil DNA extracts was contingent not only on the presence of humic substances, but also on the concentration of $E$. coli cells. Thus, dilution of $E$. coli cells attenuated the humic effects but reduced the detection limit. Only $0.25 \mathrm{~g}$ out of $200 \mathrm{~g}$ of soil was used for the DNA extraction $(=0.125 \%)$ and increasing the amount of soil used for DNA extraction (from $0.25 \mathrm{~g} / 200 \mathrm{~g}$ of soil to 5 to $10 \mathrm{~g} / 200 \mathrm{~g}$ ) did not produce any amplification due to an excess of inhibition (data not shown). The detection inconsistencies could therefore be attributed to low SCN DNA concentration.

The PCR assay developed provides a sensitive direct detection method for SCN in field soils, circumventing the time-consuming steps of nematode extraction, microscopic identification and counting, and also a tool to differentiate $\mathrm{SCN}$ from the members of $H$. schachtii group including $H$. schachtii, $H$. trifolii, and $H$. ciceri. SCN detection was efficient and consistent at high population densities ( $>349$ SCN/200 $\mathrm{g}$ of soil); however, at SCN density below $349 \mathrm{SCN} / 200 \mathrm{~g}$ of soil, detection efficiency or consistency is low, which could lead to false negative results, so multiple replications are recommended. Also, the possibility of false positives cannot be ruled out, but it is less likely due to the SCN specificity of the assay. To our knowledge, this is the first report of one assay successfully utilizing mechanical grinding of field soil, removal of PCR inhibitors, and nested PCR to detect SCN at low population densities across seven soil textural classes. This assay will be useful in detecting SCN directly from field soil at low population densities and in differentiating it from other closely related nematodes.

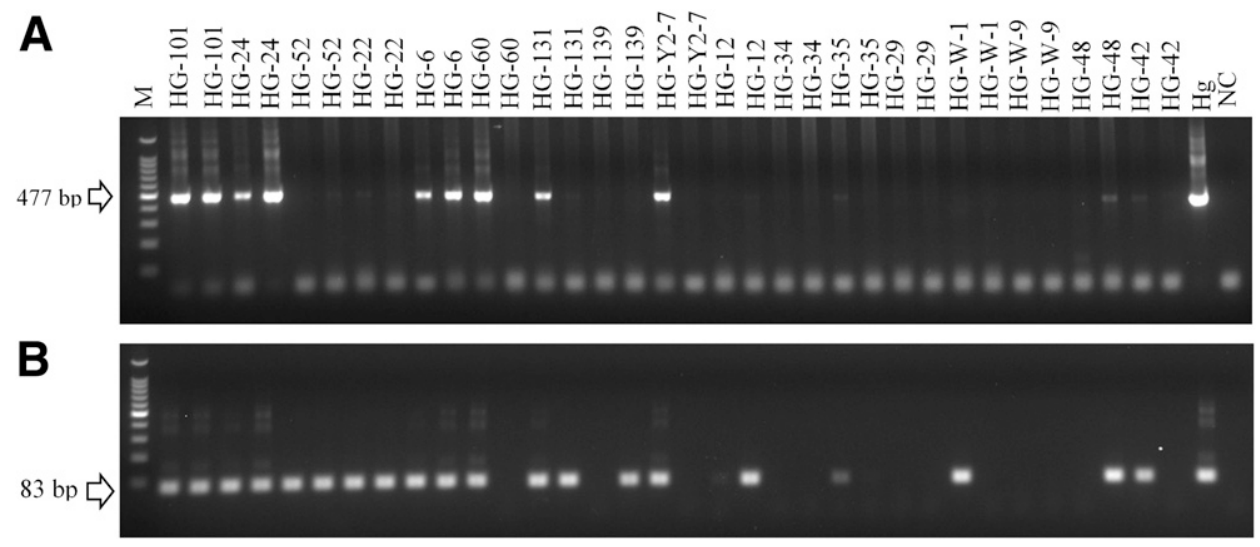

Fig. 6. SCN detection in 17 field soils with varying population densities using conventional and nested PCR. A, Nematode DNA was extracted using MoBio PowerSoil DNA extraction Kit with $\mathrm{AlNH}_{4}\left(\mathrm{SO}_{4}\right)_{2} .12 \mathrm{H}_{2} \mathrm{O}$ followed by PCR amplification with the SCN species-specific primer set SCNF1/SCNR1. B, Similar procedure as A, but with nested PCR amplification using PCR products from A and SCNrtF/SCNrtR primer set. In A, only nine samples were positive while 18 were positive in B. The soil samples were shown in Tables 1 and 3. Hg, SCN positive control; NC, water used as template; and M, 100-bp DNA ladder. 


\section{Acknowledgments}

This research was funded by the North Dakota Soybean Council. The authors express their sincere appreciation to Danqiong Huang for technical assistance, Addison Plaisance, Arjun Upadhaya, and Intiaz Chowdhury for collecting soil and nematode samples, and the growers for availing their farm properties from which soil samples were taken.

\section{Literature Cited}

Alvarez, A. J., Khanna, M., Toranzos, G. A., and Stotzky, G. 1998. Amplification of DNA bound on clay minerals. Mol. Ecol. 7:775-778.

ASTM. 1995. Standard test method for $\mathrm{pH}$ of soils. The annual book of ASTM standards, designation D4972-95a. American Society for Testing and Materials, Philadelphia, PA.

Baldwin, J. G., and Mundo-Ocampo, M. 1991. Heteroderinae, cyst and non-cystforming nematodes. Pages 275-362 in: Manual of Agricultural Nematology. W. R. Nickle, ed. Marcel Dekker, New York.

Bellvert, J., Crombie, K., and Horgan, F. G. 2008. Comparative efficiency of the Fenwick can and Schuiling centrifuge in extracting nematode cysts from different soil types. J. Nematol. 40:30-34.

Bradley, C. A., Biller, C. R., and Nelson, B. D. 2004. First report of soybean cyst nematode (Heterodera glycines) on soybean in North Dakota. Plant Dis. 88: 1287.

Braid, M. D., Daniels, L. M., and Kitts, C. L. 2003. Removal of PCR inhibitors from soil DNA by chemical flocculation. J. Microbiol. Methods 52:389-393.

Cho, J., Lee, D., Cho, Y., Cho, J., and Kim, S. 1996. Direct extraction of DNA from soil for amplification of $16 \mathrm{~S}$ rRNA gene sequences by polymerase chain reaction. J. Microbiol. 34:229-235.

Day, P. R. 1965. Particle fractionation and particle-size analysis. Pages 545-567 in: Methods of Soil Analysis, Part 1. C. A. Black, ed. American Society of Agronomists, Madison, WI.

Edzwald, J. K. 2011. Water Quality and Treatment, 6th Ed. McGraw-Hill, New York.

Erb, R. W., and Wagner-Dobler, I. 1993. Detection of polychlorinated biphenyl degradation genes in polluted sediments by direct DNA extraction and polymerase chain reaction. Appl. Environ. Microbiol. 59:4065-4073.

Frostegard, A., Courtois, S., Ramisse, V., Clerc, S., Bernillon, D., Le Gall, F., Jeannin, P., Nesme, X., and Simonet, P. 1999. Quantification of bias related to the extraction of DNA directly from soils. Appl. Environ. Microbiol. 65:5409-5420.

Goto, K., Sato, E., and Toyota, K. 2009. A novel detection method for the soybean cyst nematode Heterodera glycines Ichinohe using soil compaction and realtime PCR. Nematol. Res. 39:1-7.

Graney, L. S. O., and Miller, L. I. 1982. Comparative morphological studies of Heterodera schachtii and H. glycines. Pages 96-107 in: Nematology in the Southern Region of the United States. R. D. Riggs, ed. Southern Cooperative Series Bulletin 276, Fayetteville, AR.

Handoo, Z. A., Carta, L. K., Skantar, A. M., and Chitwood, D. J. 2012. Description of Globodera ellingtonae n. sp. (Nematoda: Heteroderidae) from Oregon. J. Nematol. 44:40-57.

Holben, W. E., Jansson, J. K., Chelm, B. K., and Tiedje, J. M. 1988. DNA probe method for the detection of specific microorganisms in the soil bacterial community. Appl. Environ. Microbiol. 54:703-711.

Hori, S. 1916. Sick soil of soybean caused by nematodes. Phytopathol. Notes 5. J. Plant Prot. 2:927-930.

Ichinohe, M. 1952. On the soybean nematode, Heterodera glycines n.sp. from Japan (trans.). Oyo-Dobutsugaku-Zasshi 17:1-4.

Jenkins, W. R. 1964. A rapid centrifugal-flotation technique for separating nematodes from soil. Plant Dis. Rep. 48:692.

Kageyama, K., Komatsu, T., and Suga, H. 2003. Refined PCR protocol for detection of plant pathogens in soil. J. Gen. Plant Pathol. 69:153-160.

Kawamura, S. 2000. Integrated design and operation of water treatment facilities, 2nd Ed. Wiley, New York.

Khanna, M., and Stotzky, G. 1992. Transformation of Bacillus subtilis by DNA bound on montmorillonite and effect of DNase on the transforming ability of bound DNA. Appl. Environ. Microbiol. 58:1930-1939.

Li, Y., Lawrence, G. W., Lu, S., Balbalian, C., and Klink, V. P. 2014. Quantitative field testing Heterodera glycines from Metagenomic DNA samples isolated directly from soil under agronomic production. PLoS One 9:e89887.

Llop, P., Bonaterra, A., Penalver, J., and Lopez, M. M. 2000. Development of a highly sensitive nested-PCR procedure using a single closed tube for detection of Erwinia amylovora in asymptomatic plant material. Appl. Environ. Microbiol. 66:2071-2078.

Lopez-Nicora, H. D., Craig, J. P., Gao, X., Lambert, K. N., and Niblack, T. L. 2012. Evaluation of cultivar resistance to soybean cyst nematode with a quantitative polymerase chain reaction assay. Plant Dis. 96:1556-1563.

McClure, M. A., Nischwitz, C., Skantar, A. M., Schmitt, M. E., and Subbotin, S. A. 2012. Root-knot nematodes in golf course greens of the Western USA. Plant Dis. 96:635-647.

McManus, P. S., and Jones, A. L. 1995. Detection of Erwinia amylovora by nested PCR and PCR-dot-blot and reverse-blot hybridizations. Phytopathology 85:618-623.

Nelson, B. D., Bolton, M. D., Lopez-Nicora, H. D., Niblack, T. L., and del Rio Mendoza, L. 2012. First confirmed report of sugar beet cyst nematode, Heterodera schachtii, in North Dakota. Plant Dis. 96:772.

Ou, S., Peng, D., Li, Y., and Wang, Y. J. 2008a. Restriction fragment length polymorphism and sequences analysis of rDNA-ITS region of cereal cyst nematode (Heterodera avenae) on wheat from Zhengzhou. Acta Phytopathol. Sin. 38:407-413.
Ou, S., Peng, D., Liu, X., Li, Y., and Moens, M. 2008b. Identification of Heterodera glycines using PCR with sequence characterized amplified region (SCAR) primers. Nematology 10:397-403.

Porteous, L. A., and Armstrong, J. L. 1991. Recovery of bulk DNA from soil by a rapid, small-scale extraction method. Curr. Microbiol. 22:345-348.

Riggs, R. D. 2004. History and distribution. Pages 9-39 in: Biology and Management of Soybean Cyst Nematode: Second Edition. Walsworth Publishing Company, Marceline, MO.

Sato, E., Min, Y. Y., Shirakashi, T., Wada, S., and Toyota, K. 2007. Detection of the root-lesion nematode, Pratylenchus penetrans (Cobb), in a nematode community using real-time PCR. Jpn J. Nematol. 37:87-92.

Showmaker, K., Lawrence, G. W., Lu, S., Balbalian, C., and Klink, V. P. 2011 Quantitative field testing Rotylenchulus reniformis DNA from metagenomic samples isolated directly from soil. PLoS One 6:e28954.

Sikora, R. A., and Maas, P. W. T. 1985. An analysis of the Heterodera trifolii complex and other species in the schachtii group attacking legumes. Pages 293-312 in: Cyst nematodes. F. Lamberti and C. E. Taylor, eds. Plenum Press, New York.

Skantar, A. M., Handoo, Z. A., Carta, L. K., and Chitwood, D. J. 2007 Morphological and molecular identification of Globodera pallida associated with potato in Idaho. J. Nematol. 39:133-144.

Subbotin, S. A., Peng, D. L., and Moens, M. 2001. A rapid method for the identification of the soybean cyst nematode Heterodera glycines using duplex PCR. Nematol. 3:365-371.

Subbotin, S. A., Ragsdale, E. J., Mullens, T., Roberts, P. A., Mundo-Ocampo, M., and Baldwin, J. G. 2008. A phylogenetic framework for root lesion nematodes of the genus Pratylenchus (Nematoda): evidence from 18S and D2-D3 expansion segments of $28 \mathrm{~S}$ ribosomal RNA genes and morphological characters. Mol. Phylogenet. Evol. 48:491-505.

Subbotin, S. A., Sturhan, D., Rumpenhorst, H. J., and Moens, M. 2003. Molecular and morphological characterization of the Heterodera avenae species complex (Tylenchida: Heteroderidae). Nematology 5:515-538

Subbotin, S. A., Waeyenberge, L., and Moens, M. 2000. Identification of cyst forming nematodes of the genus Heterodera (Nematoda: Heteroderidae) based on the ribosomal DNA-RFLPs. Nematology 2:153-164.

Subbotin, S. A., Waeyenberge, L., Molokanova, I. A., and Moens, M. 1999. Identification of Heterodera avenae group species by morphometrics and rDNA-RFLPs. Nematology 1:195-207.

Torsvik, V. L. 1980. Isolation of bacterial DNA from soil. Soil Biol. Biochem. 12:15-21.

Tsai, Y. L., and Olson, B. H. 1992. Detection of low numbers of bacterial cells in soils and sediments by polymerase chain reaction. Appl. Environ. Microbiol. 58:754-757.

Tylka, G. L., and Marett, C. C. 2014. Distribution of the soybean cyst nematode, Heterodera glycines, in the United States and Canada: 1954 to 2014. Plant Health Prog. 15:85-87.

Volossiouk, T., Robb, E. J., and Nazar, N. R. 1995. Direct DNA extraction for PCRMediated assays of soil organisms. Appl. Environ. Microbiol. 61:3972-3976.

Winstead, N. N., Skotland, C. B., and Sasser, J. N. 1955. Soybean cyst nematode in North Carolina. Plant Dis. Rep. 39:9-11.

Wrather, J. A., Anderson, T. R., Arsyad, D. M., Tan, Y., and Ploper, L. D. 2001 Soybean disease loss estimates for the top ten soybean producing countries in 1998. Can. J. Plant Pathol. 23:115-121.

Yan, G. P., and Plaisance, A. 2016. Vermiform plant-parasitic nematodes on soybean in North Dakota and their relationship with soybean cyst nematodes. American Phytopathological Society Annual Meeting, Tampa, FL, July 30-August 3.

Yan, G. P., Plaisance, A., Huang, D., Gudmestad, N. C., and Handoo, Z. A. 2016a First report of the root-lesion nematode Pratylenchus scribneri infecting potato in North Dakota. Plant Dis. 100:1023.

Yan, G. P., Plaisance, A., Huang, D., Liu, Z., Chapara, V., and Handoo, Z. A. 2016b. First report of the root-lesion nematode Pratylenchus neglectus on wheat (Triticum aestivum) in North Dakota. Plant Dis. 100:1794.

Yan, G. P., Plaisance, A., Huang, D., Upadhaya, A., Gudmestad, N. C., and Handoo, Z. A. 2016c. First report of the stubby root nematode Paratrichodorus allius on potato in North Dakota. Plant Dis. 100:1247.

Yan, G. P., and Smiley, R. W. 2010. Distinguishing Heterodera filipjevi and H. avenae using polymerase chain reaction-restriction fragment length polymorphism and cyst morphology. Phytopathology 100:216-224.

Yan, G. P., Smiley, R. W., and Okubara, P. A. 2012. Detection and quantification of Pratylenchus thornei in DNA extracted from soil using real-time PCR. Phytopathology 102:14-22.

Yan, G. P., Smiley, R. W., Okubara, P. A., and Skantar, A. M. 2013a. Species-specific PCR assay for differentiating Heterodera filipjevi and H. avenae. Plant Dis. 97:1611-1619.

Yan, G. P., Smiley, R. W., Okubara, P. A., Skantar, A. M., and Reardon, C. L. 2013b. Developing a real-time PCR assay for detection and quantification of Pratylenchus neglectus in soil. Plant Dis. 97:757-764.

Yan, G. P., Smiley, R. W., Skantar, S. A., Easley, A., Sheedy, J. G., and Thompson, A. L. 2008. Detection and discrimination of Pratylenchus neglectus and $P$. thornei in DNA extracts from soil. Plant Dis. 92:1480-1487.

Ye, W. 2012. Development of prime time-real-time PCR for species identification of soybean cyst nematode (Heterodera glycines Ichinohe, 1952) in North Carolina. J. Nematol. 44:284-290.

Zheng, J., Subbotin, S. A., Waeyenberge, L., and Moens, M. 2000. Molecular characterization of Chinese $H$. glycines and $H$. avenae populations based on RFLPs and sequences of rDNA ITS regions. Russ. J. Nematol. 8:109-133. 